\title{
CLASSIFICATION OF VILLAGES IN BAFRA DISTRICT ACCORDING TO SMALL RUMINANT EXISTENCE
}

\author{
Hasan ÖNDER ${ }^{1 *}$ \\ 1Ondokuz Mayıs University, Faculty of Agriculture, Department of Animal Science, 55139, Samsun, Turkey
}

Received: February 20, 2019; Accepted: May 06, 2019; Published: October 01, 2019

\begin{abstract}
In this study 103 villages belonged to Bafra district of Samsun province in Turkey was clustered according to existence of small ruminant (sheep and goat) to classify the villages for giving decision support to policymakers. For this aim hierarchical clustering with nearest neighborhood method and Squared Euclidean distance was used. Results showed that most of the villages had same characteristics and only two of 103 villages differ from others according to small ruminant existence. According to results same policies can be applied all the villages in Bafra district except two villages (Tepebasi and Merkez -M) which had more number of animals and business than others.
\end{abstract}

Keywords: Small ruminant, Hierarchical cluster, Policy making, Sheep, Goat

*Corresponding author: Ondokuz Mayıs University, Faculty of Agriculture, Department of Animal Science, 55139, Samsun, Turkey E mail: hasanonder@gmail.com (H. ÖNDER)

Hasan ÖNDER (iD) https://orcid.org/0000-0002-8404-8700

Cite as: Önder H. 2019. Classification of villages in Bafra district according to small ruminant existence. BSJ Eng Sci, 2(4): xx-xx.

\section{Introduction}

Small ruminant production is an essential alternative role for the farmers especially in rural harsh environment where is mountainous and marginal regions of Turkey (Atasever et al., 2015). Small ruminants both sheep and goat are being recommended as a considerable food source because of their ability convert unusable vegetation on poor pastures to meet and some other usable products (Ocak et al., 2006).

In Turkey small ruminant population is about 50.4 million head consist of 38.7 million head of sheep and 11.7 million head of goat (Sakar and Erisek, 2019; Anonymous, 2019). In Bafra district small ruminant existence is about 70000 head that raised mountainous regions (Yildirim et al., 2017). Some villages have small amount of animals and some villages has many animals. This imbalance brings some hardness for policy making for villages.
In this study, it was aimed to cluster the villages according to small ruminant existence for producing information useful for policy makers.

\section{Material and Method}

Data for the study was taken from Bafra District Agriculture and Forestry Directorate of for 103 villages of the district for the year of 2018. Small ruminant existence of villages varies from 20 to 6176 head of animals. For the statistical analysis Hierarchical cluster analysis with measure of Squared Euclidean distance and method of Nearest Neighbor (Dogan et al., 2018) was used by SPSS 20.0 version (Karaokur et al., 2019) via Ondokuz Mayis University license. Cluster analysis are one of the multivariate statistical analysis methods that are not known precisely, which contribute to grouping variables into similar group or classes (Tirink et al., 2019). 


\section{Results and Discussion}

Obtained Dendogram was given in Figure 1.

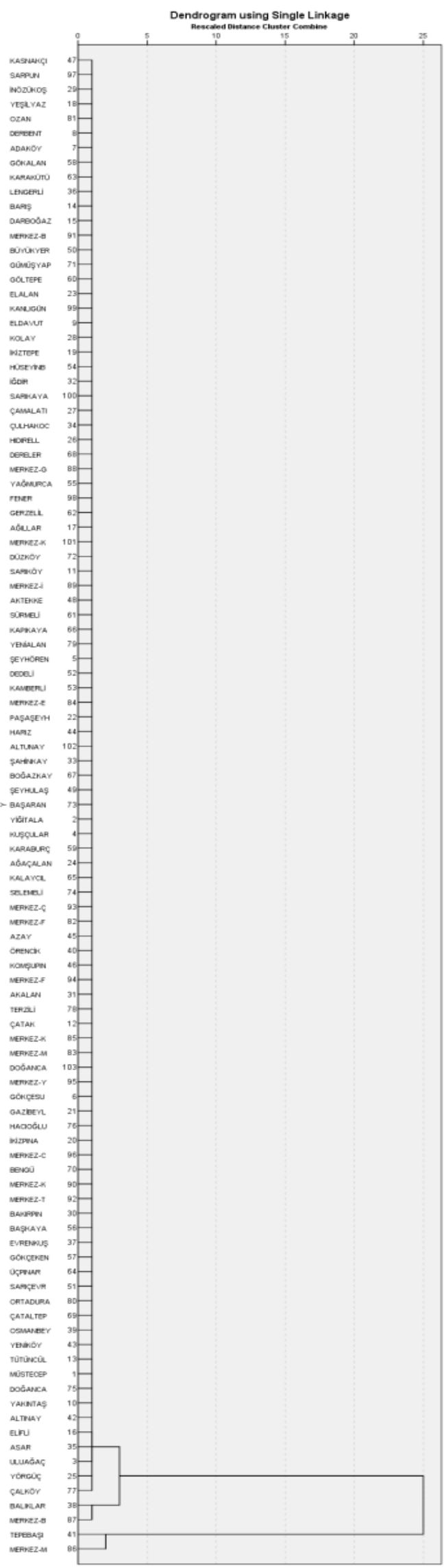

According to Figure 1 all villages of Bafra district except four (Balıklar, Merkez-Bahçeler, Tepebaşı and MerkezMevlana) were clustered in same group. Tepebaşı and Merkez-Mevlana villages were constituted another group significantly different from others. Balıklar and MerkezBahçeler villages were constituted another group significantly different from others.

According to the results it can be offered for policy makers that Tepebaşı and Merkez-Mevlana have first importance and Balıklar and Merkez-Bahçeler have second importance because these villages has $24.5 \%$ of small ruminant population among 103 villages. For these four villages pastures may be improved, heath protection should be differentially planned for these villages. Small ruminant associations should give special importance for these villages.

This results also important for traders' financial and human capital and trading practices such as use of brokers and regular suppliers and customers had varying effects on margins and costs of small ruminant trade. It is also amenable to public policy to improve the market environment and marketing efficiency (Jabbar et al., 2008).

\section{Conflict of interest}

The authors declare that there is no conflict of interest.

\section{References}

Anonymous. 2019. Turkey statistical agency data. http://www.turkstat.gov.tr/Start.do;jsessionid=wXLvcSIPLDh LQJ07FN98JGLZSVyqvyGmygb2tjLDr1yPp292Lp1d!139068546 (access date: 05.01.2019).

Atasever S, Sen U, Onder H. 2015. A study on the determination of body condition score and somatic cell count in Turkish Saanen goats. J Applied Anim Res, 43 (4): 445-449.

Dogan O, Kara N, Tonguc M. 2018. Investigation of Genetic Relationship with Yield and Essential Oil Content of Anise Populations. BSJ Agri, 1(4): 110-116.

Jabbar M, Benin S, Gabre-Madhin E, Paulos Z. 2008. Market institutions and transaction costs influencing trader performance in live animal marketing in rural Ethiopian markets. J African Econ, 17(5): 747-764.

Karaokur OF, Kaya F, Yavuz E, Yenipinar A. 2019. Comparison of commonly used statistics package programs. BSJ Eng Sci, 2(1): 26-32.

Ocak S, Guney O, Onder H. 2006. Growth and development of Cukurova Saanen kids under tropical climate conditions. JAVA, 5(11): 985-989.

Sakar CM, Erisek A. Development of Akkaraman lambs in Cankiri region from birth to 120 days. BSJ Agri, 2(1): 16-20.

Tirink C, Bayyurt L, Abaci SH, Onder H. 2019. Evaluation of dairy cattle milk production in Black Sea region by cluster analysis. BSJ Eng Sci, 2(2): 39-41.

Yildirim A, Ulutas Z, Ocak N, Kaptan M. 2017. Carcass yield, noncarcass parts, internal organs and meat quality characteristics of Karayaka male lambs with different birth weight fed freechoice feeding. Sains Malaysiana 46(3): 429-437.

Figure 1. Dendogram for villages of Bafra district according to small ruminant existence. 